\title{
Prospects and Challenges of Yoga Tourism in India and Abroad
}

\author{
Dr. Vijay Kumar \\ Assistant Professor, Dept. of Tourism, Hotel, Hospitality and Heritage Studies, Jamia Millia Islamia, \\ New Delhi 110025, India
}

\begin{abstract}
Yoga tourism has witnessed a secure growth in recent years around the world. As the number of the world's population is becoming more aware of health care options, along with an increase in the quality of health care as a priority in the minds of most age groups, patients are required to carry out cross-border healthcare.

The main reasons why yoga tourism facilities are of high quality specialized treatment, the possibility of immediate service for travel combined with affordability. In regions where the quality of care is not available, access to health care can lead to medical travel, for others, cost effectiveness could be the reason.

India has become one of the most sought after destination for medical tourism worldwide due to its high value proposition in terms of quality of health care, a pool of professionals and the availability of alternative treatments, such as Ayurveda and yoga.

However, there are several areas in tourism, which entered the field of research only recently. Yoga tourism is one such area, where only a few scientists began to work in a systematic way. The article highlights the emergence of a spiritual tourist-oriented research and explores the potential to further work in the study of tourism.
\end{abstract}

Keywords: tourism, health, wellness, India, medical tourism

\section{INTRODUCTION}

Tourism in India is not only generating value for the country, but also led to the development of a accomplished workforce. Growth is driven by a combination of expansion in income levels and routine changes, the development of a diversity of tourist offers, policy and regulatory carry by the government. Spirituality, yoga has newly become a significant subject of investigate in the areas of social and economic. It adds a new dimension to the tourism industry, as it is called Yoga tourism. "As a result, there has been increased interest in awareness and research in the field of yoga thematic tourism. Tourism is an old movement of age-related" Wellness "of civilized nations is normally used to mean a healthy balance of mind, body and spirit, which leads to an overall feeling of wellbeing."yoga and wellness tourism" it can consequently be defined as physical, mental and spiritual practice or discipline that originated in ancient India. There is a wide variety of yoga schools, practices and goals in Hinduism, Buddhism and Jainism. Among the best known types of yoga is hatha yoga and Raja yoga.

In other words, "Beauty" is the view of health that focuses on the entire being and its further development. India has always been known for its rich heritage tradition of "Wellness" and It has great opportunities to offer to applicants for "wellness". Carrera and Bridges (2006) have been defined medical tourism trip, which is systematically planned to maintain their physical and mental health.

The yoga guru from India introduced yoga in the Western countries, after the success of Swami Vivekananda in the late 19th and early 20th century. In 1980, yoga has become popular as a structure of physical exercise throughout the Western world. Yoga in the Indian tradition, however, is more than a physical exercise, a meditation and spiritual core. One of the six major schools of orthodox Hinduism is also called yoga, which has its own epistemology and metaphysics, and is closely related to the philosophy of the Hindu Samkhya.

\section{OBJECTIVES OF THE STUDY}

The study aimed at the emergence of a dominant position in the field of tourism in the world of yoga, focusing on the current state of affairs in India in the field of tourism and the way yoga promotes the industry through government. In addition, it focuses on what more foreign tourists are attracted to 
India and encourages the Indian government industry to collect foreign tourist's yoga. This work is based on literature review, including studies, websites, newspapers, magazines published, travel and tourism, which contain information on medical tourism. This research also aims to understand why some developing countries like India Yoga promote tourism effectiveness than others. It also emphasizes a competitive advantage in India to other countries.

\section{LITERATURE}

It has been experiential that spirituality and Yoga in general has recently become an important research topic in the areas of social and economic life and a new measurement to the tourism industry is added, the word yoga is derived from a Sanskrit word "Yuj" which means meditation, or to join, which refers to a process increasingly definitive liberty of the bonds of karma and rebirth. Yoga is generally practiced "the real yoga" or "hatha yoga" based on the system of Patanjali (AD c. 500) was one of the conventional system of Indian philosophy. Yoga has endured in India for many years. However, there is a current marvellous revival in yoga, particularly due to two factors, both of them related to the health field. Even though yoga has a important philosophical aspect to it, its impact on health is an obvious appeal to the common man. First, renowned physician faces difficult problems, such as asthma have begun to recognize that Western medicine, despite it's beyond doubt scientific basis, does not have all the answers. Second, we have begun to see the need for a more holistic view of human distress in all its dimensions, as seen in other systems, such as yoga.

Yoga has many advantages over most of the exercises. It is an exercise that can be done for any age group and even the fittest people. Yoga is also the most complete of all exercises, and that benefits every part of the body and internal organs.

\section{THE ROLE OF YOga AND SPIRITUALITY IN INDIAN TOURISM}

People from all over the globe move towards India for Ayurveda, yoga and meditation in Rishikesh, Uttaranchal, which is practiced for centuries. In fact, India quickly emerged as a health tourism destination because of them. From time immemorial, India has been identified for its spirituality, yoga and religious tolerance and its secular nature. India is called the "Yoga Bhoomi" and the gate of heaven. India is known throughout the world for its ancient curative practices and substitute therapies. Over thousands of years, we have to get our own systems of indigenous medicinal and healing practices such as Ayurveda, naturopathy and pranic healing, to name a few. It is no wonder that people from around the world turn to the Indian subcontinent for orientation towards a more spiritually satisfying way of life.

\section{Motives OF Foreign Tourists FOR Visiting ASHRAMS}

- The mainstream of foreign tourists visiting for yoga and spirituality believe that religious places give you peace of mind and feel spiritually fulfilled. This is since they prefer to have their tours to places rather than religious adventurous, exotic and historical monuments.

- Foreign tourists can participate in festivals and celebrations in India. They feel very well and more satisfactory in their lives.

- Nearly half of the tourists believe in Indian religions and customs and uses the rituals used in the Indian traditions. They have a desire to know the religious significance that works throughout the day, as sacred and holy Ganges River.

- Some foreign tourists even visited Satpuris willingly, including Ayodhya, Mathura, Kashi, In Ujjain and Dwarka. They feel they are not looking for luxury, but the arduous way to achieve God's intent they make life simple, more rewarding and fun.

- Foreign tourists, holy prayer bands at night on the banks of the Ganges, temples, Indian, Speeches and interaction with the monks.

- Tour operators mislead most tourists complained that tour operators take tourists misleading Different modes of transport.

- Drinking water is a necessity for everyone. But water is available in a variety of yoga is not healthy. The Everyday guests can buy a bottle of mineral water.

- Aviation Association is not available, such as Rishikesh, Kashi, Ujjain and others, as well as road infrastructure is also a problem. The only corridor and narrow railway is slow and perilous travel. 
- Bad manual tools were available another problem for them (especially in France Russia). Nieznajomość local language and the lack of information are facing problems Tourists due to lack of bilingual guide who can speak to them in their own language.

- Security believes most tourists who are dangerous when travelling by bus and walking on the streets Because of pickpockets and thieves.

- Some who seek donations have complained that they often have to spend money to fight AIDS Donations are made by unauthorized persons.

\section{Quality Standards in Hotels}

Beds various hotels were quite unsatisfactory for tourists. Quality purity proved to be very poor.

\section{Illiteracy}

Illiteracy is also a major obstacle in communication. The language barrier was another problem communication with residents.

\section{Acceptance of Credit Cards}

Due to the lack of credit card acceptance facility, the tourists have to carry money with them, which is not safe.

\section{Recreational Facilities}

Tourists find Indian Culture (tradition, music, dance, etc.) and bear fascinating joy experiencing our culture.

\section{Expectations Tourists}

Many tourists wanted some local events should be conducted as cultural dances. Some even say that should not be professional instructors to teach yoga. Yoga in comparison with other systems of meditation

\section{Islam}

In beginning of the world Persian scholar Al-Biruni in the eleventh century visited the India, an Indian living in 16 years, with several large Sanskrit translated works in Arabic and Persian. One of them was Yogasutras Patanjali. Al-Biruni's translation retained many of the main themes of the Yoga philosophy of Patanjali, but some of the sutras and analytical commentaries were transformed in a manner more in line with Islamic theology. The Al-Biruni's version of the Yoga Sutra of Persia and the Arabian Peninsula with about AD50. Później, 1050, in the 16th century, was translated by Amritakunda text Yoga into Arabic and Persian. After yoga was accepted by the Sunni Islamic and Islamic president. Islamic minority doctrines, such as the Sufi movement, especially in South Asia, adopted Indian yoga exercises, including posture and self-control. Muhammad Ghawth, Shattari mystic and one of the translators of Yoga in the 16th century changed his passion for yoga and were persecuted because of his Sufi views.

\section{Christian Meditation}

Christians integrate yoga and other Eastern spiritual aspects of prayer and meditation. This may be attributed to the desire to experience God in its fullness. In 2013, Monsignor Raffaello Martinelli (Benedict Shafi) has worked for more than 23 years, indicating that his meditation, the Christian can learn from other religious traditions (Zen, Yoga, controlled), in 2013, Monsignor Rafaelo Martini, breathing, mantra), in reference to the aspects of Christian meditation "like" the Catholic Church rejects nothing is true and holy in these religions "should therefore not refuse to use simply because they are not Christians, on the contrary, one can take them what is useful, as long as that the Christian concept of prayer, are not included in the logic and requirements. In the context of all this, that this broader to be taken and expressed again. In the past, the Catholic Church has expressed Romania and other Christian organizations concern and disagreement with some of the practices of the East and the new era, which include yoga and meditation.

\section{International Day of Yoga}

On December 11, 2014, the 193-member UN General Assembly official agreed by consensus a resolution of 21 June as "International Day of Yoga". The belief on this day came after the call for adoption on June 21 as the International Day of Yoga by Indian Prime Minister Narendra Modi in a 
speech to the UN General Assembly on September 27, 2014, suggesting June 21, which is one of two surprises, International Narendra Modi Day Yoga He said that date is the longest day in the northern hemisphere and is of particular importance in many parts of the world. The first International Yoga Day was pragmatic around the world on June 21, 2015. Approximately 35,000 people, including Indian Prime Minister Narendra Modi and many dignitaries, performed 21 asanas (yoga positions) for 35 minutes in Rajpath, New Delhi. . The yoga day, watched by millions around the world in Rajpath, established two Guinness World Records - the largest yoga class, with 35,985 people and records of the majority of nationalities participating in the group to eighty-four.

\section{Conclusion}

The tourism provides largest number of jobs in the world. India has always pointed to tourists from all over the world to experience 5000 years of civilization. Diversity of national cultures, Religions, languages, fairs and festivals, majestic nature monuments and many enchanting It can take almost the whole world. All these elements provide a unique set of capabilities, tourists to enjoy. Although the arrival of tourists is only a fraction to as Bangkok and Singapore Even in the recent boom period, connoisseur say that to attract more tourists, India have to upgrade airports, safety and security, roads and other infrastructure to world standards.

The success the tourism industry will largely depend on the success of all strategic fronts. India must change their traditional approach to the market is more competitive and modern. India has to develop unique market position, brand and image that cannot be owned by another player. India can do it presents as a place of spirituality, meditation and yoga. Places such as Rishikesh Haridwar, already known as the world's yoga capital, still has a lot of potential they attract tourists, especially foreign tourists who visit India to study yoga and break up with life.

\section{REFERENCES}

[1] Kenneth Liberman, University of Oregon, USA, 'Yoga Tourism In India'.

[2] Farooq Haq, Leonce Newby, John Jackson, 'Segmentation of the spiritual tourism market'

[3] Kotler, P., Bowen, J. and Makens, J., 2008. Marketing for hospitality and tourism. 8th edition, New Jersey: Prentice-Hall, Inc.

[4] Heather Lyon, 'Building Embodiment through Yoga Tourism in India

[5] Dr.Vinay Sharma, Ravindra Singh Tomar and Neira-Niika Ahola, 'Branding India for Health and Spiritual Tourism'

[6] Indian Medical Tourism To Touch Rs 9,500 Crore By 2015, The Economic Times, posted on IndianHealthCare.in

[7] J. M. Ali-Knight (2012), The Role Of Niche Tourism Products In Destination Development

[8] 'Narendra Modi calls for International Yoga Day', (Sep 28, 2014), The Times of India

[9] Patrick J. Holladay, Lauren M. Ponder, (2012), 'Identification-of-self through a yoga-travelspirit nexus', 308-317

[10] Richard Sharpley and Priya Sundaram, (2005), 'Tourism: a Sacred Journey? The Case of Ashram Tourism, India'

[11] http://www.aarogya.com/articles/161-yoga/232-advantages-a-disadvantages-of-yoga.html

[12] Himadri Phukan, Z. Rahman, P. Devdutt (2012), 'Emergence of Spiritual Tourism in India'.

[13] Adarsh Kumar Aggarwal, Meenal Guglani, and Dr. Raj Kumar Goel, Spiritual \& Yoga Tourism: A case study on experience of Foreign Tourists visiting Rishikesh, India, Part XI - Health, Spiritual and Heritage Tourism.

[14] Baloglu, S and McCleary, K.W. (1999) 'A Model of destination image formation', Annals of Tourist Research, 26:4,868-897

[15] http://www.researchandmarkets.com/reports/613804/booming_medical_tourism_in_india.pdf

[16] https://www.researchgate.net/publication/266868237_YOGA_TOURISM_IN_INDIA

[17] https://rawhitz.wordpress.com/2014/11/08/exploring-potentiality-of-yoga-tourism-in-westbengal/ 